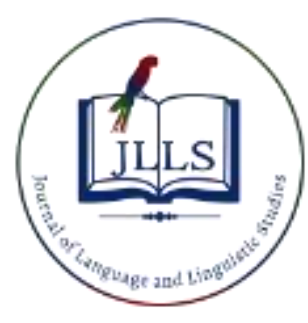

Available online at www.jlls.org

JOURNAL OF LANGUAGE

AND LINGUISTIC STUDIES

ISSN: $1305-578 \mathrm{X}$

Journal of Language and Linguistic Studies, 16(2), 883-895; 2020

\title{
The effect of the drama-based German foreign language course application on motivation and flow experience
}

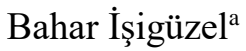 \\ ${ }^{a}$ Nevşehir Hacı Bektaş Veli University, Faculty of Education, Nevşehir, 50300, Turkey

\section{APA Citation:} \\ İşigüzel, B. (2020). The effect of the drama-based German foreign language course application on motivation and flow experience. Journal of \\ Language and Linguistic Studies, 16(2), 883-895. \\ Submission Date: $10 / 02 / 2020$ \\ Acceptance Date:09/06/2020
}

\begin{abstract}
The investigation of feelings, attitudes, and perceptions with regard to learning a foreign language takes an essential place for learning quality and success. In addition to traditional methods of learning a foreign language, the tendency towards more interactive and student-centered methods such as drama affects the teaching process positively. This study aims to examine the effect of the drama-based German foreign language course application on motivation and flow experience. The study was carried out with drama-based activities for 12 weeks in the "Drama in German Teaching" course at the Department of German Teaching of a state university in Turkey in the fall semester of the 2019 - 2020 academic year. The study was conducted with fourteen $2^{\text {nd }}$-grade students who took this course. The data were collected using the "Motivation Scale for Learning German" and the "Flow Experience Scale-Short Form" as pretest and posttest. Upon examining the average scores obtained from the scales, significant differences were determined in terms of motivation and flow experience in the drama-based German foreign language course. Accordingly, it was found that students experienced positive emotions against the dramabased German foreign language course and achieved high motivation and also had flow experience.
\end{abstract}

(C) 2020 JLLS and the Authors - Published by JLLS.

Keywords: German; drama; flow experience; motivation; foreign language.

\section{Introduction}

Cognitive processes and emotions are constantly interacting during learning. Cognition and affective dimensions affect success directly as strong stakeholders working together in learning processes. Brain studies have also revealed that emotions play an active role, and it is not possible to exclude emotions from learning processes while new information is processed in the mind (Butzkamm, 1993; Decker, 1996; Börner, 1998). Every learning experience that creates a positive attitude and makes happy supports mental skills positively (Friedrich \& Preiss, 2002; Hartinger \& Fölling-Albers, 2002). Studies conducted in the field of foreign language teaching have emphasized for a long time that cognitive factors, as well as affective and perceptual factors, are essential in the teaching process and the relationship between cognition and affection is inseparable (Schwerdtfeger, 1997; Apeltauer, 1997; Schwerdtfeger, 2001). The feelings, attitudes, and perceptions of learners with regard to learning a foreign language take an important place in the learning process. While a positive mood and high motivation during learning are 
a guarantee of success, their absence may cause negative emotions, such as worry, anxiety, and fear. While Ballweg et al. (2013) stated that the motivation factor had a strong effect on learning success in foreign language courses, Riemer (2004) emphasized that the motivation factor was responsible for successful learning processes in foreign language learning processes.

According to the cognitive-motivational process model put forward by Vollmeyer and Rheinberg (1998), learning success and motivation depend on the active learning time, the quality of learning activities, and the functional status of the learner in the learning process. The functional status of the learner in the learning process is the affective state of the person while the learning process continues. This affective state coincides with the most targeted intrinsic motivation in teaching. The reason why intrinsic motivation is targeted at most comes from the power of the learner to set his own goals by himself and perceive his own inner strength and potential in the activity as a reward without the need to be rewarded by external resources in the learning process (Apelt \& Krück 1980; Deci \& Ryan, 1985; Kleppin 2001).

One of the functional statuses of the learner in the learning process emerges in the flow theory put forward by Csikszentmihalyi $(1975,1988,1990)$. In the flow theory, it was stated that individuals in a flow state achieve higher performance during their actions performed without external rewards under the effect of their intrinsic motivation (Csikszentmihalyi, 1985; Csikszentmihalyi \& Csikszentmihalyi, 1991).

Rheinberg $(2000,2008)$ summarized what components are present in the behavior and thought dimensions during the flow experience in the theory of Csikszentmihalyi (1975) as follows:

Activity difficulty and the person's ability and skill balance: There should be a balance between the difficulty level of the activity and the person's ability level. The fact that the person's ability and skill and the difficulty level of the activity are in balance allows the person to enter the flow channel. However, anxiety may arise in cases when there is not such a balance and the activity is above one's skills, in other words, it is difficult. On the other hand, if the activity is below the person's ability, in other words, the activity is easy, the status of getting bored from the activity may arise in this situation. The three-channel flow model of Csikszentmihalyi (1975) is presented in Figure 1:

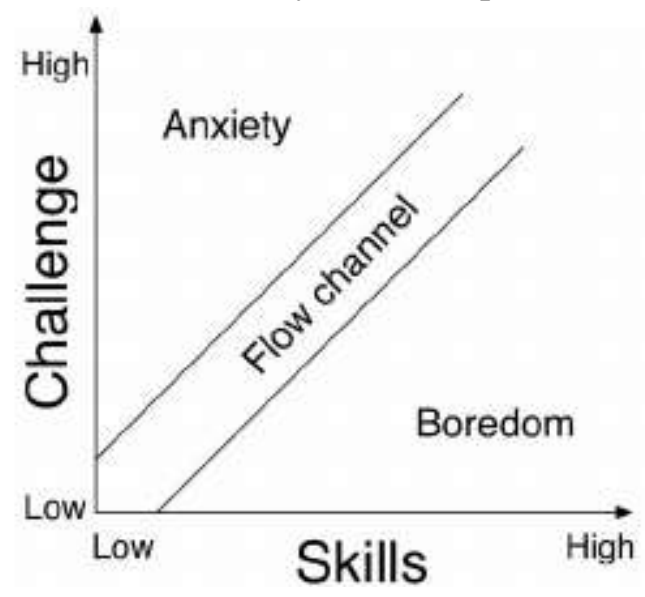

Figure 1. Three-Channel Flow Model

Fluency and process control in thoughts: Thoughts about the activity are smooth and fluent during the activity. There is no question mark in the person's mind about the content of the activity, and he knows exactly what to do at each step and thinks that he controls the entire activity process. 
Concentration on activity, easy concentration, and the loss of the time concept: The time concept is lost during the activity. The person seems to have forgotten the time and is not aware of how long he has been performing this action. The person does not understand how time passes, he is wholly absorbed in the activity and fully concentrated.

Motivation and flow experience are factors that affect learning processes positively and are thought to make significant contributions to the success of learning a foreign language. In order for these positive experiences to emerge, the teaching methods and techniques used in the teaching process emerge as an important dimension. Schewe (1993) emphasized that in addition to alternative methods, interactive, action-oriented, and experience-based methods should also be used to ensure motivation in foreign language courses. The idea of integrating the drama method with these properties into foreign language courses dates back to the mid- $19^{\text {th }}$ century. The use of drama with a communicative approach in foreign language courses developed in the $80 \mathrm{~s}$ and was accepted as a foreign language teaching method in the 90s (Schewe, 2007). There are many studies in the literature in which the drama method is now explained and used as a method in foreign language courses (Schewe \& Shaw, 1993; Kao \& O'Neill, 1998; Tselikas, 1999; Even, 2003; Wettemann, 2007; Sinisi, 2009).

Drama is an educational technique in which certain subjects are brought to life, made meaningful, and learned by means of feeling the experiences that are specially organized in a concrete way (Önder, 2003). Aral et al. (2003) defined drama as a method that increases the individual's desire for education and learning and aims at developing the person in a multi-faceted way by putting himself/herself in the place of someone else, the individual's active participation in education and teaching, expressing himself/herself, being creative, perceiving life in many ways, and developing the desire for and sense of research. The drama techniques used in this study are role play, role reversal, improvisation, visualization in mind, story / event reenactment, and drama with music.

Role play is when a person plays a role that is not his own with behaviors. Especially during the role play that requires speaking, the person includes the elements of the language spoken, such as loudness, diction, and pronunciation, and the elements of communication, such as waiting for the turn to speak, listening, not interrupting someone's else word. Role reversal means that people who play different roles change their roles and aims at enriching their learning and understanding skills by ensuring that they try and experience different roles. In the improvisation technique, as a free drama activity, people animate the flow and development of a situation or event with verbal and non-verbal, simple, spontaneous expression styles. In the visualization in mind technique, people are asked to close their eyes, visualize certain images in their minds in accordance with the instructions given by the instructor, and then explain what they see. Story and event reenactment is a technique based on people's reenacting the story and event they have already known or the story and event they have not known with movements and verbal expressions. The drama with music technique is performed in the accompaniment of a suitable musical piece related to the subject, and support is provided in expressing experiences an emotions. Especially musical pieces with a changing tempo, sometimes slowing and sometimes accelerating, are used to describe the transition from movement to movement, from state to state (Adigüzel, 2019; Önder, 2003).

\section{I. Aim and Hypotheses of the Study}

The aim of this study is to examine the effect of the drama-based German foreign language course application on motivation and flow experience. The following hypotheses were tested to decide whether there was such an effect:

1. The drama-based German foreign language course application has a positive effect on students' motivation for learning German. 
2. The drama-based German foreign language course application has a positive effect on the subdimension of interest in German culture of students' motivation for learning German.

3. The drama-based German foreign language course application has a positive effect on the subdimension of the positive classroom environment of students' motivation for learning German.

4. The drama-based German foreign language course application has a positive effect on the subdimension of social and educational opportunities of students' motivation for learning German.

5. The drama-based German foreign language course application has a positive effect on the subdimension of desire for success of students' motivation for learning German.

6. The drama-based German foreign language course application has a positive effect on students' flow experiences.

\section{Method}

\subsection{Research design}

In the study, whether the drama-based German foreign language course application had an effect on motivation and flow experience was investigated with the quantitative research design with a pretestposttest model. The research design is shown symbolically in Figure 2.

Drama Application (12 weeks)

\begin{tabular}{ccccc} 
& $\begin{array}{c}\text { Before } \\
\text { Application }\end{array}$ & 1. week & 12. week & $\begin{array}{c}\text { After } \\
\text { Application }\end{array}$ \\
\hline $\mathrm{G}$ & MM1 & FM1 & FM2 & MM2 \\
\hline
\end{tabular}

Figure 2. Research Design (MM1: Motivation Measurement 1; FM1: Flow Experience Measurement 1; MM2: Motivation Measurement 2; FM2: Flow Experience Measurement 2)

As seen in Figure 2, measurements were performed on a group in order to determine the pretest and posttest motivation for learning German and the flow experience in the $1^{\text {st }}$ and $12^{\text {th }}$ weeks.

\subsection{Study Group}

The study was carried out with drama-based activities in the "Drama in German Teaching" course as two hours a week for 12 weeks together with 14 students studying at the Department of German Teaching of a state university in Turkey in the fall semester of the 2019 - 2020 academic year. When the characteristics of the study group are examined, it is observed that $86 \%$ of the group consists of females $(\mathrm{N}: 12)$ and $14 \%$ of males $(\mathrm{N}: 2)$. The ages in the group vary between 18 and 20; $43 \%$ are 18 $(\mathrm{N}: 6), 43 \%$ are $19(\mathrm{~N}: 6)$, and $14 \%$ are $20(\mathrm{~N}: 2)$ years old.

\subsection{Application}

Drama techniques were used to identify the effect of the drama-based German foreign language course applications on motivation and flow experience (see Adıüzel, 2019; Önder, 2003). The applied drama techniques and application contents are presented in Table 1: 
Table 1. Drama Application Contents and Techniques

\begin{tabular}{|c|c|c|}
\hline Week & Application Contents & Techniques \\
\hline \multirow{2}{*}{$\begin{array}{l}1 . / 2 . \\
\text { week }\end{array}$} & Tale: Little Red Riding Hood & \multirow[b]{2}{*}{ role play } \\
\hline & Tale: Hänsel and Gretel & \\
\hline \multirow{2}{*}{$\begin{array}{l}3 . / 4 . \\
\text { week }\end{array}$} & Fable: The Wolf and the Lamb & \multirow[b]{2}{*}{ role reversal } \\
\hline & Fable:The Ant and the Cicada & \\
\hline \multirow{2}{*}{$\begin{array}{l}5 . / 6 . \\
\text { week }\end{array}$} & Topic: Life on the Desert Island! & \multirow[b]{2}{*}{ improvisation } \\
\hline & Topic:If Technology Has Not Developed? & \\
\hline \multirow{2}{*}{$\begin{array}{l}7 . / 8 . \\
\text { week }\end{array}$} & Topic:Your Name Story? & \multirow{2}{*}{$\begin{array}{l}\text { visualization in } \\
\text { mind }\end{array}$} \\
\hline & Topic: What Age To Stay? & \\
\hline \multirow{2}{*}{$\begin{array}{l}9 . / 10 . \\
\text { week }\end{array}$} & Song: "Lebe Lauter" Christina Stürmer & \multirow[b]{2}{*}{ drama with music } \\
\hline & Song:“Haus am See” Peter Fox & \\
\hline \multirow{2}{*}{$\begin{array}{l}11 . / 12 . \\
\text { week }\end{array}$} & Story: "Das Brot" W.Borchert & \multirow{2}{*}{$\begin{array}{l}\text { story and event } \\
\text { reenactment }\end{array}$} \\
\hline & Story: "Der Mann der nie zu spät kam" P. Maar & \\
\hline
\end{tabular}

As seen in Table 1, the 6 practical techniques - role play, role reversal, improvisation, visualization in mind, story and event reenactment, and drama with music - were planned as 12 applications for 12 weeks. Each technique was applied with different contents for two weeks. When the contents are considered, German literary texts such as tales, fables, and stories were used. Moreover, current issues, personal stories and views, and German songs were included in the applications. Before each application, the application contents were shared with students, and information was provided to them about the drama technique of that application. Furthermore, they were asked to do preliminary preparation according to the contents. Each application, which had two course hours a week, was held as an introduction section, main section, and closing section. The introduction section mostly began with simple movements and warm up exercises, and groups were formed at this stage, each consisting of 2 or 3 people. The groups formed in the main section started to work together, and following the designs, ideas, and discussions related to the topic, the application was conducted with the presentation of the groups according to the characteristics of the technique. In the closing section at the end of each application, mutual feedback was provided regarding the application.

\subsection{Data Collection Tools}

\subsubsection{Flow Experience Scale - Short Form}

In the study, the "Flow Experience Scale - Short Form," which is the adaptation of "Die FlowKurzskala (FKS)" developed by Rheinberg, Vollmeyer, and Engeser (2003) to Turkish by İşigüzel and Çam (2014) for university students learning a foreign language, was used as a data collection tool. The scale, which consists of a total of 13 items, has 7-point Likert-type answer options. A high score obtained from the scale indicates an increase in flow experience. The scale is comprised of two dimensions that measure flow (10 items) and anxiety ( 3 items) experience. The internal consistency coefficients of the scale were calculated as .78 for the total score, .88 for flow, and .67 for anxiety. In this study, the analyses were performed by evaluating 10 items, which measured only the flow experience, of the tool.

\subsubsection{Motivation Scale for Learning German}

In order to measure the motivation of students for learning German, "Motivationsfragebogen: Warum lernst du Deutsch?" developed by Schlak et al. (2002) and the "Motivation Scale for Learning German" 
adapted to Turkish by Çam, Serindağ, and İşigüzel (2010) for students learning a foreign language were used. The scale consists of 4 sub-dimensions (Interest in German culture, positive classroom environment, social and educational opportunities, and desire for success), each containing 5 items, and 20 items in total. The items have 5-point Likert-type answer options. The internal consistency coefficients vary between .67 and .78 for the sub-scales; this value is .82 for the total scale. A high score means high motivation.

\subsection{Data Collection and Analysis}

The "Motivation Scale for Learning German" was applied in the classroom environment for pretest measurement before the beginning of the lessons and for posttest measurement after all the lessons. The data obtained from the "Flow Experience Scale - Short Form" were collected as pretest and posttest data in the $1^{\text {st }}$ and $12^{\text {th }}$ weeks via the experience sampling method (ESM) while drama-based activities were carried on. The ESM aims at approaching the experiences of people during the activity as closely as possible. For this reason, it is recommended that flow experience data should be collected and measured by taking a break in the activity at a time when the focus on the activity is at the peak level (Csikszentmihalyi \& Larson, 1987; Csikszentmihalyi \& Csikszentmihalyi, 1991; Rheinberg \& Vollmeyer, 2001). The application of the scale takes 3-5 minutes on average, and the data can be collected immediately, after which the activity can be continued. For data analysis, SPSS Statistics 22 Program was used. The significance level was considered as 0.01 in the interpretation of the results.

The Kolmogorov-Smirnov test was applied in order to determine whether the collected data met the normality assumption. The results of the normality test for all the measurements are presented in Table 2:

Table 2. Normality Test

\begin{tabular}{|c|c|c|c|c|c|}
\hline & & & \multicolumn{3}{|c|}{ Kolmogorov-Smirnov } \\
\hline & & & Statistic & $\mathrm{df}$ & Sig. \\
\hline \multirow[t]{2}{*}{ Motivation } & & Pretest & .181 & & .200 \\
\hline & & Posttest & .172 & 13 & .200 \\
\hline Motivation & interest in German & Pretest & .156 & & .200 \\
\hline \multirow[t]{7}{*}{ Sub - Dimensions } & culture & Posttest & .224 & 13 & .055 \\
\hline & positive classroom & Pretest & .202 & & .128 \\
\hline & environment & Posttest & .183 & 13 & .200 \\
\hline & social / educational & Pretest & .189 & & .190 \\
\hline & opportunities & Posttest & .214 & 13 & .081 \\
\hline & desire for success & Pretest & .254 & & .015 \\
\hline & & Posttest & .180 & 13 & .200 \\
\hline \multirow[t]{2}{*}{ Flow Experience } & & Pretest & .173 & & .200 \\
\hline & & Posttest & .117 & 13 & .200 \\
\hline
\end{tabular}

According to the Kolmogorov-Smirnov normality test results, the significance value of the data obtained from the scales is higher than 0.01. Thus, it is observed that the data met the assumption of a normal distribution. According to this result, the T-test (Paired Samples T-Test) among parametric tests was used for related samples in the analyses of the scales. 


\section{Results}

\subsection{Motivation Findings}

The results of the T-test conducted for the significance of the difference between the pretest and posttest mean scores that were obtained from the motivation scale are presented in Table 3.

Table 3. T-Test Results of the Pretest and Posttest Mean Scores for Motivation

\begin{tabular}{lcccccc}
\hline Motivation & $\mathrm{N}$ & $\overline{\mathrm{X}}$ & $\mathrm{SD}$ & $\mathrm{df}$ & $\mathrm{t}$ & Sig. \\
\hline Pretest & 14 & 59.00 & 11.98 & 13 & -5.70 & .000 \\
\hline Posttest & 14 & 75.57 & 7.83 & & & \\
\hline
\end{tabular}

When the pretest-posttest scores of the motivation scale in Table 3 were examined, a significant difference was observed in favor of the posttest mean scores [t=-5.70, $\mathrm{p}<.01]$. Accordingly, it can be stated that the hypothesis that 'The drama-based German foreign language course application has a positive effect on students' motivation for learning German' was confirmed.

The results of the T-test conducted for the significance of the difference between the pretest and posttest mean scores obtained from the sub-dimensions of the motivation scale are given in Table 4 .

Table 4. T-Test Results of the Pretest and Posttest Mean Scores for Motivation Sub-Dimensions

\begin{tabular}{|c|c|c|c|c|c|c|c|}
\hline $\begin{array}{l}\text { Sub - Dimensions } \\
\text { of Motivation }\end{array}$ & $\mathrm{N}$ & & $\overline{\mathrm{X}}$ & $\mathrm{SD}$ & df & $\mathrm{t}$ & Sig. \\
\hline \multirow{2}{*}{$\begin{array}{l}\text { interest in German } \\
\text { culture }\end{array}$} & 14 & Pretest & 14.35 & 4.48 & 13 & -2.98 & .006 \\
\hline & & Posttest & 20.92 & 6.49 & & & \\
\hline \multirow{2}{*}{$\begin{array}{l}\text { positive classroom } \\
\text { environment }\end{array}$} & 14 & Pretest & 11.42 & 2.90 & 13 & -8.91 & .000 \\
\hline & & Posttest & 16.85 & 1.79 & & & \\
\hline \multirow{2}{*}{$\begin{array}{l}\text { social and } \\
\text { educational } \\
\text { opportunities }\end{array}$} & 14 & Pretest & 14.00 & 4.07 & 13 & -6.24 & .000 \\
\hline & & Posttest & 17.00 & 3.01 & & & \\
\hline \multirow[t]{2}{*}{ desire for success } & 14 & Pretest & 19.21 & 2.15 & 13 & -4.04 & .001 \\
\hline & & Posttest & 20.78 & 1.92 & & & \\
\hline
\end{tabular}


When the pretest and posttest scores of the sub-dimensions of the motivation scale were reviewed, a significant difference was observed in favor of the interest in German culture $(\mathrm{t}=-2.98)$, positive classroom environment $(\mathrm{t}=-8.91)$, social and educational opportunities $(\mathrm{t}=-6.24)$, and desire for success $(\mathrm{t}=-4.04)$ posttest mean scores $(\mathrm{p}<0.01)$. Consequently, the hypotheses stating that the dramabased German foreign language course application has a positive effect on the interest in German culture, positive classroom environment, social and educational opportunities, and desire for success sub-dimensions of students' motivation for learning German were confirmed.

\subsection{Flow Experience Findings}

The results of the T-test conducted for the significance of the difference between the flow experience mean scores are presented in Table 5.

Table 5. T-Test Results of the Pretest and Posttest Mean Scores for Flow Experience

\begin{tabular}{lcccccc}
\hline $\begin{array}{l}\text { Flow } \\
\text { Experience }\end{array}$ & $\mathrm{N}$ & $\overline{\mathrm{X}}$ & $\mathrm{SD}$ & $\mathrm{df}$ & $\mathrm{t}$ & Sig. \\
\hline Pretest & 14 & 25.35 & 3.67 & 13 & -54.77 & .000 \\
\cline { 1 - 2 } Posttest & 14 & 48.85 & 3.03 & & & \\
\hline
\end{tabular}

When the pretest and posttest scores of flow experience, the measurement of which was carried out in the $1^{\text {st }}$ and $12^{\text {th }}$ weeks, were examined, a significant difference was observed in favor of the posttest mean scores $[\mathrm{t}=-54.77, \mathrm{p}<.01]$. Accordingly, the hypothesis stating that 'The drama-based German foreign language course application has a positive effect on students' flow experiences' was confirmed.

\section{Discussion}

According to the results of the study, it was revealed that the drama method caused an increase in flow experience and motivation by creating positive feelings for foreign language courses. In the light of these results, learners can exhibit higher performance when they feel less anxious in foreign language teaching processes and experience positive learning environments. Positive learning environments affect the functional statuses of learners and pave the way for achieving intrinsic motivation.

In previous studies, the relationships between flow experience and success in foreign language courses were investigated. In a study carried out with students taking foreign language courses at university, Bischoff (2003) concluded that flow experience increased the learning performance. Similarly, in a study conducted by Engeser et al. (2005) in the language learning environment of a foreign language course, the relationship between flow experience and success scores was checked, and eventually, a significant moderate relationship was discovered between success scores and flow experience. In the literature, no flow experience activities in the drama-based foreign language courses were encountered.

With the drama-based foreign language courses, it is possible to say that teaching processes which have high motivation, no anxiety, and high possibility of success and which are more positive than traditional methods can be experienced. On the contrary, as revealed in Fischer's $(2005,2007)$ studies, the success scores of learners who were anxious during the production of a foreign language speech 
decreased as their level of anxiety increased. In a study, Sirisrimangkorn (2012) found that students had a more positive perception, high motivation and self-confidence with drama-based foreign language courses. Bournot-Trites et al. (2007) discovered that students in the experimental group had a higher level of motivation than the control group in French lessons with drama application. In their global simulation project using the drama method in foreign language courses, Dicks and Le Blanc (2009) obtained high motivation outcomes. Piazzoli (2011), on the other hand, revealed that drama reduced some participants' level of language anxiety in foreign language courses. In their study, Ralph (1997) and Aita (2009) stated that drama increased the self-confidence of learners and their motivation increased in foreign language learning processes.

\section{Conclusions}

This study tried to investigate the effect of the drama-based German foreign language course application on motivation and flow experience. For this purpose, six hypotheses were tested, and the following results were obtained:

An increase was observed in the motivation of the students, who participated in the drama applications for learning German, following the applications. It can be said that they developed a positive attitude towards foreign languages with drama applications and experienced fewer negative feelings such as anxiety and fear. The inability to experience positive feelings such as motivation in foreign language courses brings about negative feelings such as anxiety and fear. A positive attitude towards the language that will be learned can directly influence the success of the process. According to Apeltauer (1997), motivation is a factor defined as "the key to success" in the foreign language teaching process.

Furthermore, a positive effect was observed on the sub-dimensions of interest in German culture, positive classroom environment, social and educational opportunities, and desire for success, as on their general motivation, after the application. The inclusion of the topics (tale, song, short story) belonging to the German culture in the application contents of the study enabled an increase in the interest in the cultural dimension and strengthening of the method. In this context, the curiosity of students about the foreign language they are learning and their interest in that culture can be expected to make the learning process more quality and significant.

The increase in the sub-dimensions of positive classroom environment, social and educational opportunities, and desire for success, as stated by Aral et al. (2003), may result from the contribution to the development of the feelings of those learning with drama such as self-confidence, cooperation, responsibility, solidarity, and sharing. According to Even (2003: 147), drama-based courses enable learners to gain "self-respect, self-confidence, and ability of empathy."

The positive effect of drama applications on students' flow experience was observed in the posttest. Loehr (1986) referred to it as a rewarding existence in itself, in which energetic, enjoyable, selfconfident, and physical relaxation is experienced with flow experience and the effect of the main concentration and intrinsic motivation of learners. Accordingly, the fact that the learners played an active role in the process and experienced interacted, active, and cooperative learning in the student-centered drama applications also contributed to their functional statuses in a positive way. The most desired goals in learning processes are the full involvement of learners in an activity, their reference to the activity as fascinating, and their ability to keep the process under control by losing track of time and fully concentrating on the activity. In foreign language courses, it is considered possible for students to exhibit higher performance in the activities they take part in with their own internal desire.

In drama-based foreign language courses, student-centered and interactive learning processes affect the motivation for learning and flow experience positively, possibly resulting in learning success. 
According to Even (2003), drama-based foreign language courses also contribute to the development of language awareness and autonomous learning. During drama applications, "thinking deeply about the foreign language, having information about the target language (meaning, language forms, and use), becoming sensitive to one or several languages, and making an effort to improve their communication with the use of the language in daily life show that they have language awareness" (Ballweg et al. 2013:74). With the encouragement of autonomous learning in drama applications, learners take responsibility for their own language learning processes and make progress in an independent and goaloriented way.

\section{Ethics Committee Approval}

The author(s) confirm(s) that the study does not need ethics committee approval according to the research integrity rules in their country (Date of Confirmation: June 10, 2020).

\section{References}

Adıgüzel, Ö. (2019). Eğitimde Yaratıcı Drama. İstanbul: Yapı Kredi Yayınları.

Aita, S. (2009). The Theatre in Language Learning (TILL) Model: Exploring Theatre as Pedagogy in the L2 Environment. Scenario, 3(1),70-89.

Aral, N., Baran, G., Pedük, Ş., \& Erdoğan, S. (2003). Eğitimde Drama. İstanbul: YA-PA Yayınları.

Apelt, W., \& Krück, B. (1980). Motivationsproblematik im Fremdsprachenunterricht - Kritische Bemerkungen zu "modernen" Motivationsinterpretationen. Deutsch als Fremdsprache, 17(1), 1-12.

Apeltauer, E. (1997).Grundlagen des Erst-und Fremdsprachenerwerbs. Eine Einführung Fernstudieneinheit, 15. Kassel: Langenscheidt.

Ballweg, S., Drumm, S., Hufeisen, B., Klippel, J., \& Pilypaityte, L. (2013). dll - deutsch lehren lernen 2. Wie lernt man die Fremdsprache Deutsch? dll-deutsch lehren lernen: Fort- und Weiterbildung weltweit. Stuttgart: Klett Langenscheidt.

Bischoff, J. (2003). Lernmotivation, Flow-Erleben und Leistung in universitären Fremdsprachenkursen (Unveröffentliche Diplomarbeit). Institut für Psychologie der Universität Postdam.

Bournot-Trites, M., Belliveau, G., Spiliotopoulos, V., \& Seror, J. (2007). The Role of Drama on Cultural Sensitivity, Motivation and Literacy in a Second Language Context. Journal for Learning through the Arts, 3(1),1-35.

Börner,W. (1998). Anmerkungen zum fremdsprachlichen Wissen. In K.R. Bausch, H. Christ, F. G.Königs, \& H.J. Krumm, (Eds.), Kognition als Schlüsselbegriff bei der Erforschung des Lehrens und Lernens fremder Sprachen, Arbeitspapiere der 18, Frühjahrskonferenz zur Erforschung des Fremdsprachenunterrichts (pp.28-33). Tübingen: Narr.

Butzkamm, W. (1993). Psycholinguistik des Fremdsprachenunterrichts: Von der Muttersprache zur Fremdsprache.Tübingen / Basel: Francke Verlag.

Çam S., Serindă̆ E., \& İşigüzel B. (2010). Almanca Öğrenmeye Yönelik Motivasyon Ölçeği'nin Türkçeye Uyarlama, Geçerlik ve Güvenirlik Çalışması. Çukurova Üniversitesi Sosyal Bilimler Enstitüsü Dergisi, 19, 302-312.

Csikszentmihalyi, M. (1975). Beyond boredom and anxiety. San Francisco: Jossey-Bass Publishers. 
Csikszentmihalyi, M. (1985). Das Flow-Erlebnis. Jenseits von Angst und Langeweile: im Tun aufgehen. Stuttgart: Klett-Cotta.

Csikszentmihalyi, M. (1988). The future of flow. In M. Csikszentmihalyi ve I. Csikszentmihalyi (Eds.), Optimal experience: Psychological studies of flow in consciousness (pp. 364-383). New York: Cambridge University Press.

Csikszentmihalyi, M. (1990). Flow: The psychology of optimal experience. New York: Harper \& Row.

Csikszentmihalyi, M., \& Csikszentmihalyi, I. S. (1991). Die außergewöhnliche Erfahrung im Alltag. Die Psychologie des Flow-Erlebnisses. Stuttgart: Klett-Cotta.

Csikszentmihalyi, M., \& Larson, R. (1987). Validity and reliability of the Experience Sampling Method. Journal of Nervous and Mental Disease, 175, 529 - 536.

Deci, E. L., \& Ryan, R. M. (1985). Intrinsic motivation and self-determination in human behavior. London: Plenum Press.

Decker, F. (1996). Die neuen Methoden des Lernens und der Veränderung:Lern- und Organisationsentwicklung mit NLP, Kinesiologie und Mentalpädagogik. München: AOL- Lexika Verlag.

Dicks, J. E., \& Le Blanc, B. (2009). Using Drama for Learning to Foster Positive Attitudes and Increase Motivation: Global Simulation in French Second Language Classes. Journal for Learning through the Arts, 5(1), 1-40.

Engeser, S., Rheinberg, F., Vollmeyer, R., \& Bischoff, J. (2005). Motivation, Flow Erleben und Lernleistung in universitären Lernsettings. Zeitschrift für Pädagogische Psychologie, 19, 159 - 172.

Even, S. (2003). Drama Grammatik: Dramapädagogische Ansätze für den Grammatikunterricht Deutsch als Fremdsprache. München: Iudicium.

Fischer, S. (2005). Sprechmotivation und Sprechangst im DaF-Unterricht. German as a Foreign Language, 3, 31- 45.

Fischer, S. (2007). Sprechfähigkeit und - willigkeit fördern: Das Dilemma der Grammatik-Vermittlung. Zeitschrift für Interkulturellen Fremdsprachenunterricht, 12(1), 1-23.

Friedrich, G., \& Preiss,G. (2002). Neurodidaktik: Lehren mit Köpfchen. Gehirn \& Geist, 2(4), 64-70.

Hartinger, A., \& Fölling-Albers, M. (2002). Schüler Motivieren und Interessieren. Ergebnisse aus der Forschung Anregungen für die Praxis. Bad Heilbrunn: Verlag Julius Klinkhardt.

İşigüzel, B., \& Çam, S. (2014). Flow Yaşantısı Ölçeği Kısa Formunun Türkçeye uyarlama, geçerlik ve güvenirlik çalışması. International Journal of Human Sciences, 11(2), 788-801.

Kao, S. M., \& O’Neill, C. (1998). Words into worlds: Learning a second language through process drama. London: Ablex Publishing.

Kleppin, K. (2001). Motivation, Nur ein Mythos? (I). Deutsch als Fremdsprache, 38, 219-225.

Loehr, J. E. (1986). Mental toughness training for sports: Achieving athletic excellence. New York: Plume.

Önder, A. (2003). Yaşayarak Öğrenme için Eğitici Drama. Kuramsal Temellerle Uygulama Teknikleri ve Örnekleri. İstanbul: Epsiyon Yayınevi. 
Piazzoli, E. (2011). Process Drama: the Use of Affective Space to Reduce Language Anxiety in the Additional Language Learning Classroom. The Journal of Applied Theatre and Performance, 16(4), 557-573.

Ralph, E. (1997). The Power of Using Drama in the Teaching of Second Languages: Some Recollections. McGill Journal of Education, 32, 273-288.

Riemer, C. (2004). Zur Relevanz qualitativer Daten in der neueren L2- Motivationsforschung. In W. Börner, \& K. Vogel (Eds.), Emotion und Kognition im Fremdsprachenunterricht (pp. 35-65). Tübingen: Narr Verlag.

Rheinberg, F. (2000). Motivation. Stuttgart: Kohlhammer.

Rheinberg, F., \& Vollmeyer, R. (2001). Flow-Erleben: Untersuchungen zu einem populären, aber unterspezifizierten Konstrukt (DFG Forschungsantrag). Universität Postdam Institut für Psychologie.

Rheinberg, F., Vollmeyer, R., \& Engeser, S. (2003). Die Erfassung des Flow-Erlebens. In J. StiensmeierPelster \& F. Rheinberg (Eds.), Diagnostik von Motivation und Selbstkonzept (pp. 261-279). Göttingen: Hogrefe interspezifizierten Konstrukt.

Rheinberg, F. (2008). Intrinsic motivation and flow-experience. In J. Heckhausen \& H. Heckhausen, (Eds.), Motivation and Action (pp. 323-348). Cambridge: Cambridge University Press.

Schewe, M. (1993). Fremdsprache inszenieren. Zur Fundierung einer dramapädagogischen Lehr- und Lernpraxis. Oldenburg: Carl von Ossietzky Universität Oldenburg.

Schewe, M., \& Shaw, P. (1993). Towards Drama as a Method in the Foreign Language Classroom. Frankfurt/Main: Peter Lang.

Schewe, M. (2007). Drama und Theater in der Fremd- und Zweitsprachenlehre. Blick zurück nach vorn. Scenario, 1(1), 154-169.

Schlak, T. Banze, K., Haida, J., Kilinc, T., Kirchner, K., \& Yilmaz, T. (2002). Die Motivation von DaFLernenden an Sprachlehrinstitutionen im Bielefelder Raum: Projektbeschreibung und erste Ergebnisse. Zeitschrift für Interkulturellen Fremdsprachenunterricht, 7(2). Retrieved on February 8,2020, from: https://tujournals.ulb.tu-darmstadt.de/index.php/zif/article/download/572/548

Schwerdtfeger, I.C. (1997). Der Unterricht Deutsch als Fremdsprache: Auf der Suche nach den verlorenen Emotionen. Info DaF, 24(5), 587-606.

Schwerdtfeger, I.C. (2001). Gruppenarbeit und innere Differenzierung. Fernstudieneinheit 29. Berlin: Langenscheidt.

Sinisi, B. (2009). Drama im DaF-Unterricht zur Förderung der Sprechfertigkeit: Ein Theaterprojekt anhand von Sketchen Karl Valentins. Scenario, 2, 22-46.

Sirisrimangkorn, L. (2012). The effects of drama-based role play structured by stad on university students' speaking skill, motivation, and self-esteem [unpublished doctoral dissertation]. Institute of Social Technology Suranaree University of Technology.

Tselikas, E. I. (1999). Dramapädagogik im Sprachunterricht. Zürich: Orell Füssli.

Vollmeyer, R., \& Rheinberg, F. (1998). Motivationale Einflüsse auf Erwerb und Anwendung von Wissen in einem computersimullerten System. Zeitschrift für Pädagogische Psychologie, 12, 11-23.

Wettemann, U. (2007). Kein trockener Anfängerunterrichtmehr! Eine dramapädagogische Modelleinheit für die ersten DaF-Stunden. Scenario, 1, 66-91. 


\section{Drama temelli Almanca yabancı dil ders uygulamasının motivasyon ve flow yaşantısına etkisi}

\section{$\ddot{O} \mathbf{z}$}

Yabancı bir dili öğrenmeye yönelik duyguların, tutumların ve algıların araştırılması öğrenme niteliği ve başarısı için önemli bir yer tutmaktadır. Geleneksel yabancı dil yöntemlerinin yanı sıra drama gibi daha etkileşimli ve öğrenci merkezli yöntemlere eğilim gösterilmesi öğretim sürecini olumlu yönde etkileyebilmektedir. Bu çalışmanın amacı, drama temelli Almanca yabancı dil ders uygulamasının motivasyon ve flow yaşantısına etkisini incelemektir. Araştırma 2019 - 2020 öğretim yılı güz yarıyılında Türkiye’deki bir devlet üniversitesinin Almanca öğretmenliği Bölümünde "Almanca Öğretiminde Drama" dersinde 12 hafta boyunca drama temelli etkinliklerle gerçekleştirilmiştir. Bu dersi alan 2. sınıfta öğrenim gören 14 öğrenci ile çalışma yürütülmüştür. Veriler öntest ve sontest olarak “Almanca Öğrenmeye Yönelik Motivasyon Ölçeğii” ve "Flow Yaşantısı Ölçeği Kısa Formu” ile toplanmıştır. Ölçeklerden alınan puanların ortalamalarına bakıldığında, drama temelli gerçekleştirilen Almanca yabancı dil derslerinde motivasyon ve flow yaşantısı açısından anlamlı farklılıklar saptanmıştır. Buna göre drama temelli yapılan Almanca yabancı dil derslerine karşı̈ ögrenenlerin olumlu duygular yaşayarak yüksek motivasyona ulaştıkları ve flow yaşantısını da deneyimledikleri belirlenmiştir.

Anahtar sözcükler: Almanca; drama; flow yaşantısı; motivasyon; yabancı dil.

\section{AUTHOR BIODATA}

Bahar İşigüzel is working as an Assoc. Prof. Dr. in the department of Foreign Language Teaching at Nevşehir Hacı Bektaş Veli University. She received her Ph.D. in German Language Teaching from Çukurova University. Her research areas include motivation in foreign language learning, flow experience in foreign language classes and foreign language classroom anxiety. 